\title{
IMPLEMENTASI ALGORITMA SAW(SIMPLE ADDITIVE WEIGHTING) DEMPSTER SHAFER PADA DIAGNOSA AWAL POSTPARTUM DEPRESSION
}

Page | 1

\author{
Yuli Kartika Sari ${ }^{1}$, Dwi Kartini ${ }^{2}$, Muliadi ${ }^{3}$ \\ ${ }^{123}$ Program Studi Ilmu Komputer Fakultas MIPA Universitas Lambung Mangkurat \\ Jalan Ahmad Yani Km. 36, Kampus Unlam Banjarbaru, Kalimantan Selatan 70714,Indonesia \\ 1'yulikartikas05@gmail.com, ${ }^{2}$ dwikartini@unlam.ac.id, ${ }^{3}$ muliadi@unlam.ac.id
}

\begin{abstract}
Abstrak - Depresi Postpartum (Postpartum Depression) merupakan salah satu bentuk depresi yang dialami ibu setelah melahirkan bayi pertama dan berlangsung pada tahun pertama setelah kelahiran bayi. Hal ini disebabkan karena periode tersebut merupakan periode transisi kehidupan baru yang cukup membuat stress namun tidak semua ibu mampu melakukan adaptasi dan mengatasi stressor tersebut sehingga timbul keluhan-keluhan antara lain berupa stres, cemas dan depresi. Penelitian ini mengimplementasikan penggabungan Metode Simple Additive Weighting dan Dempster Shafer digunakan dalam melakukan diagnosa awal depresi postpartum berdasarkan basis pegetahuan yang diperoleh dari pakar seorang psikolong dan bidan yang direperesentasikan ke dalam sistem pakar. Input yang digunkana berupa sub-sub gejala yang dialami pasien pasca melahirkan yang akan dikonversikan menjadi nilai 1 kemudian diproses menggunakan metode Simple Additive Weighting untuk menentukan nilai belief gejala. Setelah nilai belief gejala tersebut digunakan untuk malakukan diagnosa awal Postpartum Depression dengan metode Dempster Shafer. Hasil akurasi sistem berdasarakan data rekam medic pasien sebesar $\mathbf{9 0 \%}$.
\end{abstract}

Keywords — Sistem Pakar, Postpartum Depression, Simple Additive Weighting, Dempster Shafer.

\section{PENDAHULUAN}

Dignosa awal penyakit Postpartum Depression pada sistem pakar memerlukan adanya sebuah mesin inferensi yang dikenal juga sebagai struktur kontrol atau penerjemah atauran. Komponen ini sebenarnya adalah program komputer yang menyediakan metodologi untuk mempertimbangan informasi dalam basis pengetahuan dan blackboard dan merumuskan kesimpulan. Komponen ini menyediakan arahan bagaimana menggunakan pengetahuan sistem, yakni dengan mengembangkan agenda yang mengatur dan mengontrol langkah yang diambil untuk memecahkan persoalan kapanpun konsultasi berlangsung. Metode yang sering digunakan dalam melakukan diagnosa penyakit medis adalah metode Dempster Shafer.

Teori ini dikembangkan oleh Arthur P. Dempster dan Glenn Shafer. Pada umumnya, penelitianpenelitian yang membuat sistem pakar dengan menggunakan metode Dempster Shafer hanya menggunakan basis pengetahuan berupa data penyakit dan data gejala seperti pada penelitian Anis Mistanti (2004) yang berjudul "Sistem Pakar Untuk Memprediksi Penyakit Pada Tanaman Cabai Menggunakan Metode Dempster Shafer". Akan tetapi, terdapat juga beberapa penyakit atau gangguan lainnya yang memiliki sub gejala dalam basis pengetahuannya seperti salah satunya adalah gangguan Postpartum Depression atau depresi pasca ibu melahirkan.

Berdasarkan latar belakang permasalahan diatas, maka diperlukan metode tambahan yang dapat digunakan untuk menghitung bobot sub gejala tersebut sebagai nilai belief gejala pada proses Dempster Shafer. Salah satu metode yang paling sering digunakan dalam pembobotan suatu kriteria adalah metode SAW (Simple Additive Weighting). Metode SAW dapat memberikan penilaian berdasarkan input sub gejala yang dirasakan pasien dengan bobot sub gejala yang diperoleh dari pakar. Output metode SAW (Simple Additive Weighting) yang nantinya akan digunakan sebagai nilai belief gejala dalam melakukan diagnosa awal Postpartum Depression.

Data Rekam Medik pada penelitian ini didapatkan dari salah satu Bidan Praktek Mandiri yang ada di daerah Banjarbaru. Pada penelitian ini peneliti ingin melakukan penggabungan metode SAW dan Dempster Shafer dalam memberikan rekomendasi diagnose awal postpartum depression dan tindakan bagi ibu pasca melahirkan.

\section{TINJAUAN PUSTAKA}

\section{A. Definisi Sistem Pakar}

Sistem pakar adalah aplikasi berbasis komputer yang digunakan untuk menyelesaikan masalah sebagaimana yang dipikirkan oleh pakar. Pakar yang 
dimaksud di sini adalah orang yang mempunyai keahlian khusus yang dapat menyelesaikan masalah yang tidak dapat diselesaikan oleh orang awam. Sebagai contoh, dokter adalah seorang pakar yang mampu mendiagnosa penyakit yang diderita pasien serta dapat memberikan penatalaksanaan terhadap penyakit tersebut. Tidak semua orang dapat mengambil keputusan mengenai diagnosis dan memberikan penatalaksanaan suatu penyakit[1].

Tujuan pengembangan sistem pakar sebenarnya tidak untuk menggantikan peran para pakar, namun untuk mengimplementasikan pengetahuan para pakar ke dalam bentuk perangkat lunak, sehingga dapat digunakan oleh banyak orang dan tanpa biaya yang besar. Untuk membangun sistem yang difungsikan untuk menirukan seorang pakar manusia harus bisa melakukan hal-hal yang dapat dikerjakan oleh para pakar [2].

\section{B. Postpartum Depression}

Depresi postpartum (Postpartum Depression) adalah salah satu bentuk depresi yang dialami ibu setelah melahirkan bayi pertama dan berlangsung pada tahun pertama setelah kelahiran bayi. Hal ini disebabkan karena periode tersebut merupakan periode transisi kehidupan baru yang cukup membuat stres, dimana ibu harus beradaptasi dengan perubahan fisik, psikologis dan sosial yang dialaminya karena melahirkan dan mulai merawat bayi. Namun tidak semua ibu mampu melakukan adaptasi dan mengatasi stressor tersebut sehingga timbul keluhan-keluhan antara lain berupa stres, cemas dan depresi [3].

Menurut Diagnostic and Statistical Manual of Mental Disorder-IV, ada 3 jenis bentuk depresi pasca melahirkan, yaitu :

1. Postpartum Blues yang merupakan gangguan mood yang bersifat sementara.

2. Depresi Postpartum tanpa gambaran psychosis yang lebih berat dari Postpartum Blues.

3. Postpartum Psychosis, yaitu depresi berat berupa gangguan proses pikir yang dapat mengancam keselamatan jiwa ibu dan bayinya sehingga memerlukan bantuan psikiater.

Selain ketiga bentuk depresi diatas, gangguan kejiwaan yang dapat dialami pasca persalinan adalah Delusi dan Skizofrenia. Delusi adalah satu jenis penyakit mental psikosis yang ditandai dengan ketidaksinambungan antara pemikiran dan emosi sehingga penderitanya kehilangan kontak dengan realitas sebenarnya. Sedangkan Skizofrenia adalah gangguan mental kronis yang menyebabkan penderitanya mengalami halusinasi, pikiran kacau, dan perubahan perilaku.

\section{SAW (Simple Additive Weighting)}

Metode Simple Additive Weighting sering juga dikenal dengan istilah metode penjumlahan berbobot. Konsep dasar metode SAW ini adalah mencari penjumlahan terbobot dari rating kinerja pada setiap alternatif pada semua atribut. Metode SAW disarankan untuk menyelesaikan masalah penyeleksian dalam sistem pengambilan keputusan multi proses. Metode SAW merupakan metode yang banyak digunakan dalam pengambilan keputusan yang memiliki banyak atribut. Perhitungan matrix alternatif dibagi menjadi dua, yaitu perhitungan Atribut benefit dan cost, rumus perhitungan Atribut dapat dilihat pada persamaan dibawah ini.

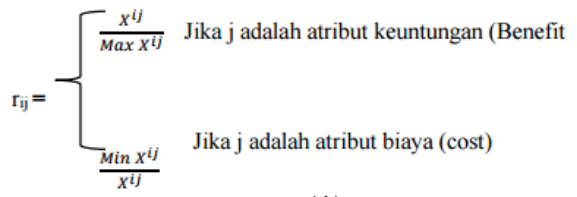

Dimana :

(1)

rij = rating kerja ternormalisasi

Maxij = nilai maximum dari setiap baris dan kolom

Minij = nilai minimum dari setiap baris dan

kolom

$\mathrm{Xij}=$ baris dan kolom dari matrix

Dimana rij adalah rating kinerja ternormalisasi dari alternatif Ai pada atribut $\mathrm{Cj}: \mathrm{i}=1,2, \ldots, \mathrm{m}$ dan $\mathrm{j}$ $=1,2, \ldots, \mathrm{n}$. rumus perhitungan nilai preferensi untuk setiap alternatif (Vi) pada persamaan dibawah ini.

$$
V_{i}=\sum_{j=1}^{n} w_{j}(2)
$$

Dimana

$\mathrm{Vi}=$ Nilai akhir dari alternative

$\mathrm{Wj}=$ Bobot yang telah ditentukan

rij = Normalisasi matriks

Dari persamaan diatas dapat ditarik kesimpulan bahwa jika nilai Vi lebih besar mengindikasikan bahwa alternatif Ai lebih terpilih[4].

\section{Dempster Shafer}

Teori Dempster-Shafer adalah suatu teori matematika untuk pembuktian berdasarkan belief functions and plausible reasoning (fungsi kepercayaan dan pemikiran yang masuk akal), yang digunakan untuk mengkombinasikan potongan informasi yang terpisah (bukti) untuk mengkalkulasi kemungkinan dari suatu peristiwa. Teori ini dikembangkan oleh Arthur P. Dempster dan Glenn Shafer [5].

Secara umum Teori Dempster-Shafer ditulis dalam suatu interval:

\section{[Belief, Plausibility]}

Belief (Bel) adalah ukuran kekuatan evidence (bukti) dalam mendukung suatu himpunan proposisi. Jika bernilai 0 maka mengindikasikan bahwa tidak 
ada evidence, dan jika bernilai 1 menunjukkan adanya kepastian. Plausability (Pl) dinotasikan sebagai:

$$
\operatorname{Pl}(s)=1-\operatorname{Bel}(\neg s)
$$

Plausability juga bernilai 0 sampai 1 . Jika yakin $\neg$ s, maka dapat dikatakan bahwa $\operatorname{Bel}(\neg s)=1$, dan

Page $13 \quad P l(\neg s)=0$. Pada teorema Dempster-Shafer kita mengenal adanya frame of discernment yang dinotasikan dengan $\theta$. Frame ini merupakan semesta pembicaraan dari sekumpulan hipotesis. Tujuan adalah membangkitkan kepercayaan elemen-elemen $\theta$. Tidak semua evidence secara langsung mendukung tiap-tiap elemen. Sebagai contoh, panas mungkin hanya mendukung $\{\mathrm{F}, \mathrm{D}, \mathrm{B}\}$ Untuk itu perlu adanya probabilitas densitas (m). Nilai $m$ tidak hanya mendefinisikan elemen-elemen $\theta$ saja, namun juga semua subset-nya. Sehingga jika $\theta$ berisi $\mathrm{n}$ elemen, maka subset dari $\theta$ semua berjumlah $2 n$. Nilai yang dihasilkan dari teori ini berupa persentase tiap elemen-elemen $\theta$, dan juga semua subset-nya. Makin rendah persentase frame of discernment menggambarkan makin baik tingkat pemahaman pasien dalam materi tersebut. Penilaian diberikan kepada elemen-elemen berdasarkan hasil persentasi ini:

$$
\mathrm{m}_{3}(\mathrm{z})=\frac{\sum_{x n y=z} m 1(X) \cdot m 2(Y)}{1-\sum_{x n y=\phi^{m}} m 1(x) \cdot m 2(Y)}
$$

\section{METODE PENELITIAN}

\section{A. Prosedur Penelitian}

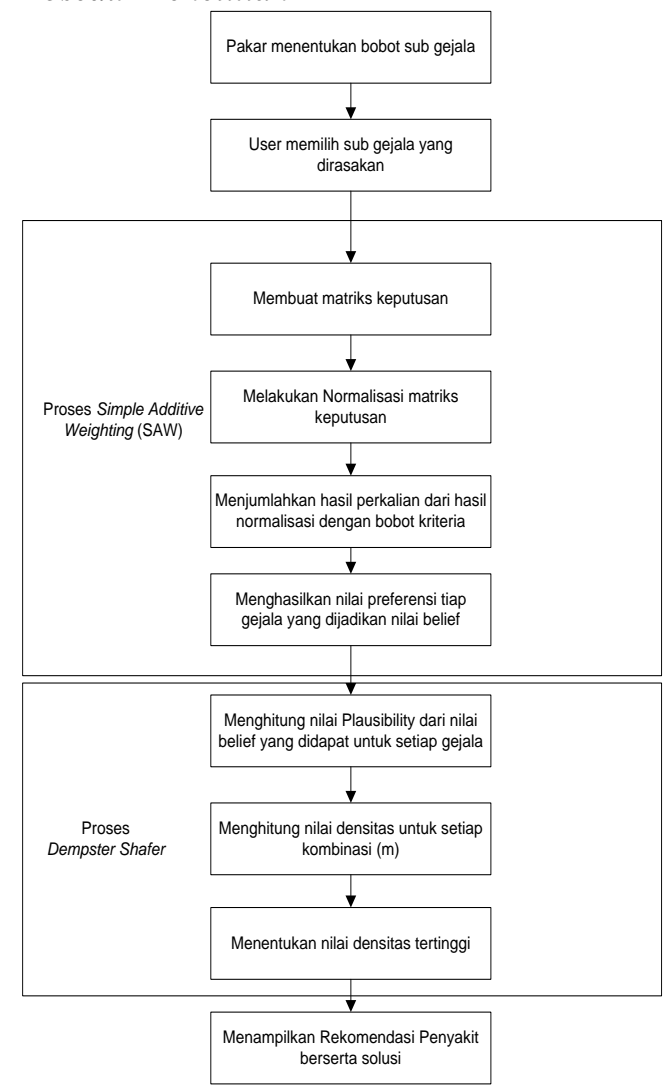

Gambar 1. Alur penelitian Sistem Pakar Postpartum Depression
Alur penelitian yang dilakukan adalah sebagai berikut:

1. Penentuan Bobot Sub Gejala oleh Pakar

Pada tahap ini, dilakukan wawancara dengan pakar psikologi untuk menentukan bobot sub gejala yang akan digunakan untuk proses SAW (Simple Additive Weighting).

2. Pemilihan Sub Gejala yang Dirasakan Pasien

Pada tahapan ini dilakukan pemilihan sub gejala yang dirasakan ibu pasca melahirkan. Pasien hanya menjawab pilihan dengan mencentang checkbox berdasarkan sub gejala yang dialaminya.

3. Pembuatan Matriks Keputusan

Pada tahapan ini dilakukan pembuatan matriks keputusan sub gejala yang telah di pilih oleh pasien, sub gejala tersebut akan dikelompokkan berdasarkan gejala-gejala yang telah didapatkan berdasarkan tabel pengetahuan.

4. Normalisasi Matriks Keputusan

Pada tahapan ini dilakukan normalisasi matriks keputusan ke suatu skala yang dapat diperbandingkan dengan semua rating alternatif yang ada.

5. Penjumlahan Hasil Perkalian Hasil Normalisasi dengan Bobot Kriteria

Pada tahapan ini dilakukan penjumlahan dari perkalian elemen baris ternormalisasi dengan bobot preferensi sub gejala yang didapat dari pakar yang akan dijadikan nilai belief pada proses Dempster Shafer.

6. Penghitungan Nilai Preferensi

Nilai preferensi dihitung berdasarkan langkah sebelumnya, nilai preferensi tersebut akan dijadikan nilai belief pada proses Dempster Shafer.

7. Penghitungan Nilai Plausibility

Pada tahapan ini dilakukan penghitungan nilai Plausibility dengan menggunakan nilai belief yang sebelumnya didapatkan.

8. Penghitungan Nilai Densitas

Tahapan ini nilai densitas dihitung dengan menggunakan persamaan kombinasi aturan Dempster Shafer .

9. Penentuan Nilai Densitas Tertinggi

Setelah nilai densitas selesai dihitung, maka langkah selanjutnya adalah menentukan nilai densitas tertinggi. Nilai densitas tertinggi itulah yang akan dijadikan rekomendasi penyakit oleh sistem.

10. Penampilan Hasil Rekomendasi Penyakit dan Solusi

Hasil rekomendasi penyakit beserta solusi akan ditampilkan pada interface sistem dengan mengklik tombol "Klik".

\section{PEMBAHASAN}

\section{A. Analisa dan Konseptual}

Setelah dilakukan pengumpulan data berdasarkan tatapmuka dan tanya jawab dengan pakar psikolog maka peneliti mendapatkan infromasi mengenai gangguan Postpartum Depression, antara lain :

1. Jenis Gangguan Postpartum Depression 
Gangguan Postpartum Depression terdiri 5 jenis gangguan dapat dilihat pada tabel 1.

TABEL I

JENIS GANGGUAN

\begin{tabular}{|l|l|}
\hline Kode & \multicolumn{1}{|c|}{ Nama Gangguan } \\
\hline P001 & Postpartum Blues \\
\hline P002 & Postpartum Depression \\
\hline P003 & Postpartum Psychosis \\
\hline P004 & Delusi \\
\hline P005 & Skizofrenia \\
\hline
\end{tabular}

2. Gejala Gangguan Postpartum Depression

Gejala gangguan Postpartum Depression terdiri dari 19 gejala yang dapat dilihat pada tabel 2 .

TABEL II

GEJALA GANGGUAN POSTPARTUM DEPRESSION

\begin{tabular}{|c|l|}
\hline Kode & \multicolumn{1}{|c|}{ Nama Gejala } \\
\hline G001 & $\begin{array}{l}\text { Sering terbangun diwaktu tidur } \\
\text { (nnsomnia) }\end{array}$ \\
\hline G002 & Konsentrasi Menurun \\
\hline G003 & Cemas \\
\hline G004 & Merasa Sedih \\
\hline G005 & Enggan Memberikan ASI \\
\hline G006 & \begin{tabular}{l} 
Enggan Memberikan Kenyamanan pada \\
\hline G007
\end{tabular} \\
\hline G008 & Merasa Bayi tersebut tidak diharapkan \\
\hline G009 & Mood Swing \\
\hline G010 & Menurunnya Semangat \\
\hline G011 & Ingin Bunuh Diri \\
\hline G012 & Menyakiti Diri Sendiri \\
\hline G013 & Menyakiti Bayi Anda \\
\hline G014 & Waham \\
\hline G015 & Berhalusinasi \\
\hline G016 & Trauma \\
\hline G017 & Egois \\
\hline G018 & Berprilaku Abnormal \\
\hline G019 & Paranoid \\
\hline & \\
\hline
\end{tabular}

3. Sub Gejala Gangguan Postpartum Depression

Masing-masing gejala memiliki sub gejala dengan nilai bobot yang diperoleh dari pakar psikolog. Basis pengetahuan dari sub gejala dan bobot dari gejala gangguan Postpartum Depression dapat dilihat pada tabel 3 .

TABEL III

SUB GEJALA GANGGUAN POSTPARTUM DEPRESSION

\begin{tabular}{|c|c|c|}
\hline $\begin{array}{c}\text { Kode } \\
\text { Sub } \\
\text { Gejala }\end{array}$ & \multicolumn{1}{|c|}{ Nama Sub Gejala } & $\begin{array}{c}\text { Bobo } \\
\mathrm{t}\end{array}$ \\
\hline SG_01 & $\begin{array}{l}\text { Sering terbangun ditengah malam hari, } \\
\text { sehingga mengantuk keesokan di siang } \\
\text { harinya }\end{array}$ & 0.2 \\
\hline SG_02 & $\begin{array}{l}\text { Merasa sulit untuk memulai tidur atau } \\
\text { tidak bisa menutup mata }\end{array}$ & 0.4 \\
\hline
\end{tabular}

\begin{tabular}{|c|c|c|}
\hline SG_03 & $\begin{array}{l}\text { Belakangan ini bisa mudah tertidur, tetapi } \\
\text { bangun terlalu awal dan tidak bisa tidur } \\
\text { kembali }\end{array}$ & 0.2 \\
\hline SG_04 & Sering merasakan nyeri dibagian perut & 0.1 \\
\hline SG_05 & $\begin{array}{l}\text { Ketika dimalam hari saat tidur, akan } \\
\text { mengalami tangan yang berkeringat }\end{array}$ & 0.1 \\
\hline SG_06 & $\begin{array}{l}\text { Belakangan ini banyak melakukan } \\
\text { pekerjaan sekaligus tanpa ada skala } \\
\text { prioritas }\end{array}$ & 0.3 \\
\hline SG_07 & $\begin{array}{l}\text { Belakangan ini sering mengkonsumsi obat } \\
\text { anti depressan maupun penenang }\end{array}$ & 0.4 \\
\hline SG_08 & $\begin{array}{l}\text { Sering melakukan aktivitas yang menguras } \\
\text { tenaga tanpa beristirahat }\end{array}$ & 0.2 \\
\hline SG_09 & $\begin{array}{l}\text { Sering lupa dengan lokasi/tempat dari } \\
\text { suatu objek yang ingin anda cari }\end{array}$ & 0.1 \\
\hline$\ldots$. & $\ldots \ldots \ldots .$. & $\ldots .$. \\
\hline$\ldots$. & $\ldots \ldots \ldots$ & $\ldots .$. \\
\hline$\ldots .$. & $\ldots \ldots \ldots$ & $\ldots .$. \\
\hline SG_58 & $\begin{array}{l}\text { Sering mencurigai hal-hal yang ada } \\
\text { disekitar anda dengan konotasi negatif }\end{array}$ & 0.4 \\
\hline
\end{tabular}

\section{B. Basis Pengetahuan gangguan Postpartum Depression}

Dibawah ini merupakan tabel yang digunakan sebagai acuan dalam pembuatan sistem pakar gangguan Postpartum Depression. Mesin inferensi untuk basis pengetahuan gangguan Postpartum Depression dapat dilihat pada tabel 4.

TABEL IV

DAFTAR HUBUNGAN GEJALA DAN GANGGUAN

\begin{tabular}{|c|c|c|c|c|c|}
\hline Gejala & $\begin{array}{c}\text { PPB } \\
\text { (1) }\end{array}$ & $\begin{array}{c}\text { PPD } \\
\text { (P002) }\end{array}$ & $\begin{array}{c}\text { PSYCH } \\
\text { OSIS } \\
\text { (P003) }\end{array}$ & $\begin{array}{c}\text { DELU } \\
\text { SI }\end{array}$ & $\begin{array}{c}\text { SKIZOF) } \\
\text { RENIA } \\
\text { (P005) }\end{array}$ \\
\hline G001 & $\checkmark$ & $\checkmark$ & $\checkmark$ & $\checkmark$ & $\checkmark$ \\
\hline G002 & $\checkmark$ & $\checkmark$ & $\checkmark$ & $\checkmark$ & $\checkmark$ \\
\hline G003 & $\checkmark$ & $\checkmark$ & $\checkmark$ & $\checkmark$ & $\checkmark$ \\
\hline G004 & $\checkmark$ & & & & \\
\hline G005 & $\checkmark$ & & & & \\
\hline G006 & $\checkmark$ & & & & \\
\hline G007 & $\checkmark$ & & & & \\
\hline G008 & & $\checkmark$ & & $\checkmark$ & \\
\hline G009 & & $\checkmark$ & & & \\
\hline G010 & & $\checkmark$ & & & \\
\hline G011 & & $\checkmark$ & & & \\
\hline G012 & & $\checkmark$ & & & \\
\hline G013 & & $\checkmark$ & & & \\
\hline G014 & & & $\checkmark$ & $\checkmark$ & \\
\hline G015 & & & $\checkmark$ & & \\
\hline G016 & & & $\checkmark$ & & \\
\hline G017 & & & & $\checkmark$ & \\
\hline G018 & & & & & $\checkmark$ \\
\hline G019 & & & & & \\
\hline
\end{tabular}




\section{Implementasi Program}

1. Halaman Input Data Login

Halaman ini adalah halaman dimana pengguna diminta untuk memasukkan pasien name dan password agar nantinya dapat masuk sebagai admin dari sistem.

Page | 5

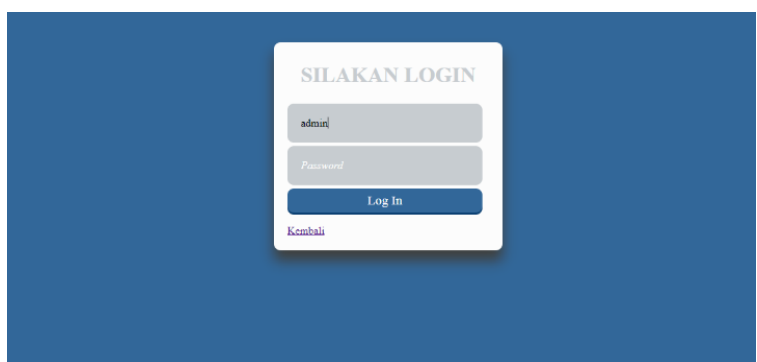

Gambar 2. Halaman login Admin

2. Halaman Menu Input Data Gangguan

Halaman ini merupakan halaman data gangguan dimana semua list data gangguan beserta keterangan dari gangguan yang ada pada sistem akan ditampilkan.

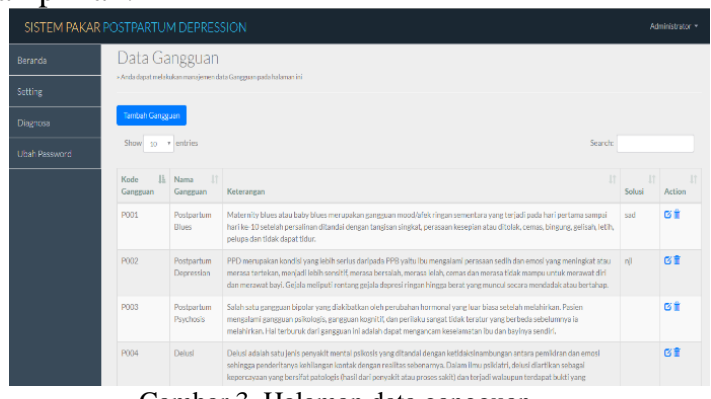

Gambar 3. Halaman data gangguan

3. Halaman Input Data Gejala

Halaman ini adalah halaman yang admin dapat melihat data gejala baru pada sistem.

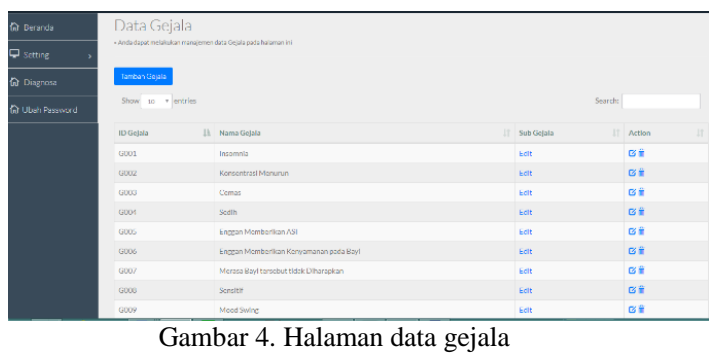

4. Halaman Input Data Sub Gejala

Halaman ini adalah halaman admin yang dapat melihat dan melakukan manajemen data sub gejala.

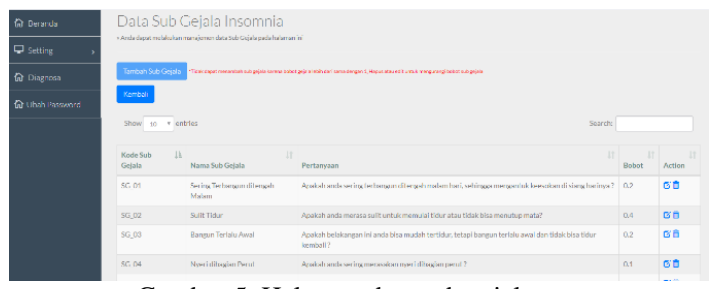

Gambar 5. Halaman data sub gejala
5. Halaman Input Data Relasi

Halaman ini adalah halaman admin yang dapat melihat data hubungan antara gangguan dengan gejala yang bersesuaian berdasarkan informasi dari pakar atau ahli yang ada.

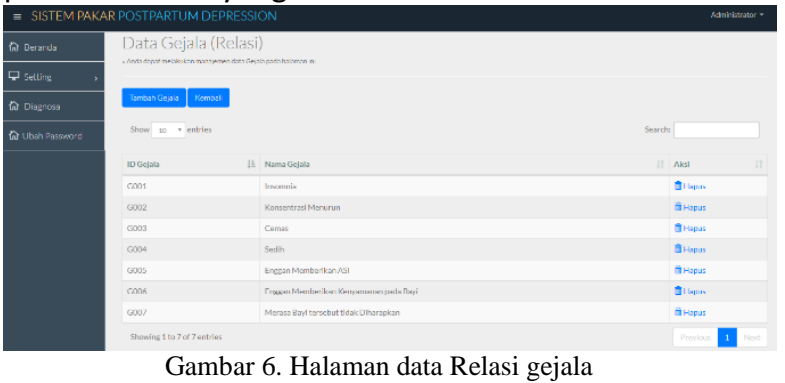

6. Halaman Diagnosis

Halaman ini adalah halaman bagi user (pasien) memilih sub gejala berdasarkan keluhan yang dirasakan.

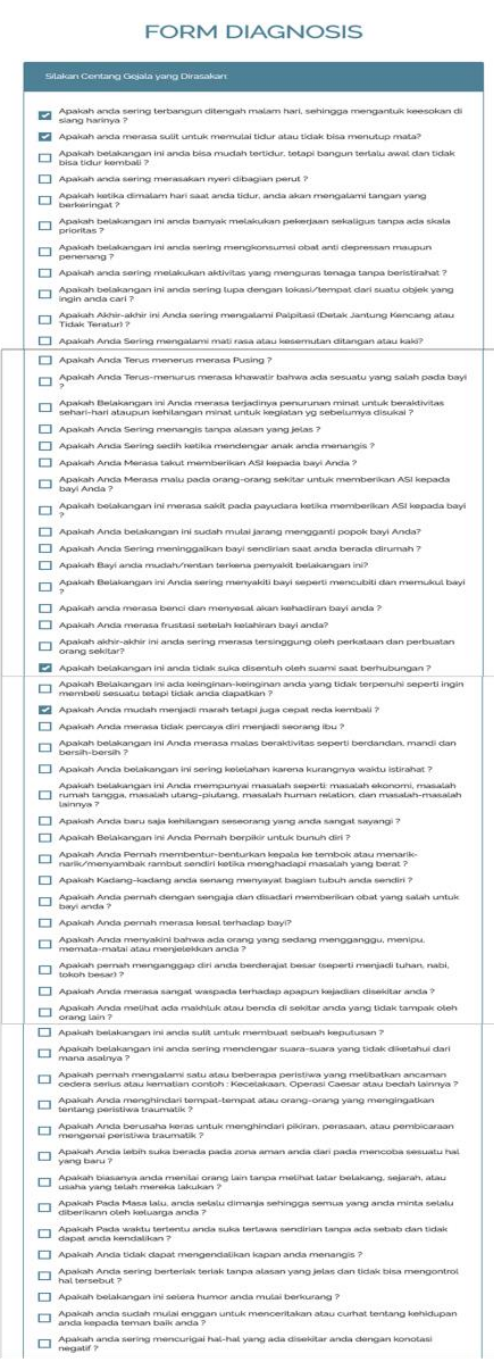

Gambar 7. Halaman Diagnosis

7. Halaman Perhitungan Diagnosa

Halaman ini akan ditampilkan setelah pengguna telah memilih gejala dan menekan button diagnosa penyakit. Pada halaman ini dilakukan proses metode 
Simple Additive Weighting berdasarkan sub gejala yang dirasakan oleh pasien untuk mencari nilai preferensi (V) yang diperoleh dari penjumlahan dari perkalian elemen baris ternomalisasi dengan bobot preferensi gejala yang didapat dari pakar yang kemudian nilai preferensi sebagai nilai belief akan diproses kembali menggunakan metode Dempster Page 16 Shafer dalam mendiagnosa awal gangguan Postpartum Depression.

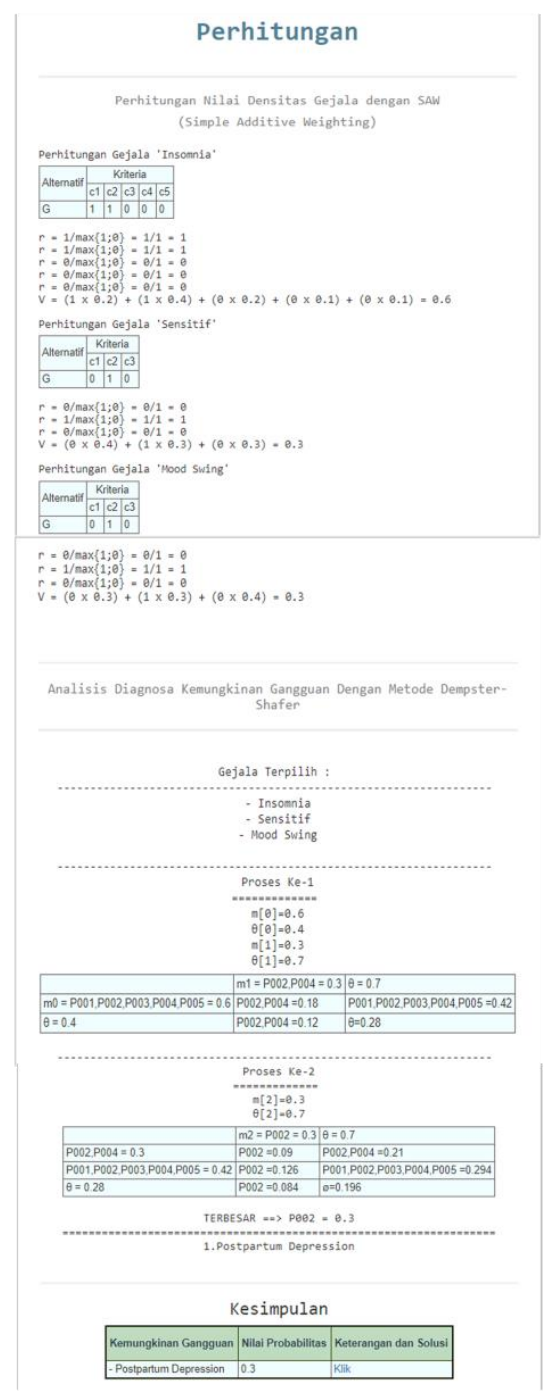

Gambar 8. Halaman Perhitungan Diagnosa

\section{PENUTUP}

\section{A. Kesimpulan}

Dari hasil penelitian yang telah dilakukan, dapat diambil beberapa kesimpulan sebagai berikut :

1. Metode SAW (Simple Additive Weighting) dapat digunakan dalam penentuan nilai belief gejala pada metode Dempster Shafer berdasarkan bobot subgejala yang didapatkan dari pakar. Tingkat akurasi sistem yang didapatkan dari penelitian ini adalah sebesar $90 \%$.

2. Metode SAW dan Dempster Shafer dapat memberikan diagnosa awal gangguan Postpartum Depression berdasarkan gejalagejala yang telah diinformasikan penderita.

3. Hasil implementasi diagnosa gangguan Postpartum Depression yang telah diujikan pada sistem pakar berdasarkan data rekam medik sebesar $90 \%$.

\section{B. Saran}

Dari penelitian yang telah dilakukan, peneliti dapat memberikan saran untuk penelitian selanjutnya agar dapat mencoba metode pembobotan yang lain guna mendapatkan bobot yang benar-benar dapat merepresentasikan pengetahuan pakar. Diharapkan peneliti selanjutnya juga dapat menelaah dan mengkaji dengan lebih dalam mengenai sub gejala dan gejala pada bidang psikologi karena terdapat banyak sub gejala yang samar.

\section{REFERENSI}

[1] Kusrini. 2006. "Sistem Pakar (Teori dan Aplikasi)". Andi Offset: Yogyakarta.

[2] Istiqomah, Y.N \& A. Fadlil. 2013. "Sistem Pakar Untuk Mendiagnosa Penyakit Saluran Pencernaan Menggunakan Metode Dempster Shafer". Jurnal Sarjana Teknik Informatika. Vol. 1, No.1.

[3] Hutagaol, E.T. 2010. "Efektivitas Intervensi Edukasi Pada Depresi Postpartum". Tesis Ilmu Keperawatan program Magister Ilmu Keperawatan Kekhususan Keperawatan Maternitas.

[4] Nofrianysah, Dicky. 2012. "Konsep Data Mining VS Sistem Pendukung Keputusan”. Yogyakarta: CV. Budi Utama.

[5] Kusumadewi, Sri. 2003. Artificial Intelligence (Teknik dan Aplikasinya).Yogyakarta: : Graha Ilmu.

[6] Mistanti, Anis. 2014."Sistem Pakar untuk memprediksi penyakit Pada Tanaman Cabai Menggunakan Metode Dempster Shafer". Jurnal Informatika Budi Darma. Vol. VI. No.1

[7] Sari, Dewi.M. 2012. "Sistem Pakar Untuk Diagnosa Penyakit Pada Tanaman Buah Naga Menggunakan Metode Dempster Shafer". Skripsi Universitas Islam Negeri Sultan Syarif Kasim Riau Pekanbaru. 